\title{
Assessing Students' Knowledge of Owls from their Drawings and Written Responses
}

\author{
Torkar Gregor $^{1}$, Tanja Gnidovec ${ }^{1}$, Sue Dale Tunnicliffe ${ }^{2}$, and Iztok Tomažič ${ }^{3}$ \\ ${ }^{1}$ University of Ljubljana, Faculty of Education, Slovenia \\ ${ }^{2}$ University College London, UK \\ ${ }^{3}$ University of Ljubljana, Biotechnical Faculty, Slovenia
}

Abstract

Many children learn about and experience animals in the everyday environment where they live and attend school. One way to obtain information about children's understanding of concepts or phenomena is using their drawings in combination written responses or interviews. This study assesses how much Slovenian students ten to fifteen years old (in sixth to ninth grade) know about owls by analyzing their drawings and written responses. The study included 473 students. From assessing students' drawings and written responses, it can be concluded that the respondents had some knowledge of owls' appearance, their behaviors, diet and habitats. The differences between students in different grades regarding the representations of owls proved to be insignificant. Some students had misconceptions about owls, such as the idea that owls can turn their heads 360 degrees or they confused the long ear-tufts with external parts of the ears. The students' written responses provided more information on their ideas about owls; particularly about owls' specific behaviors, diet, and conservational status. However, some information, such as depicting owls' body parts and body proportions or their habitats, was more clearly depicted with drawings. One third of students draw owls in trees and forests, which makes owls good candidates for promoting forest conservation.

Keywords: owls, knowledge, lower secondary students, drawings, written responses

\section{Introduction}

From their earliest years, children learn about and experience animals in the everyday environment where they live and attend school (Tunnicliffe 2011). They notice animals in the real world, in the media, and in representations in household items such as children's wallpaper and soft toys (Tunnicliffe et al. 2008). Looking after animals and direct observations of animals positively influence children's understanding of animals' biology (Hantano and Inagaki 1997; Inagaki 1990; Prokop and Tunnicliffe 2010; Tunnicliffe and 
Reiss 1999a). For example, Prokop and Tunnicliffe (2010) found that having pets at home was associated with more positive attitudes toward, and greater familiarity with, both popular and unpopular animals. Children's knowledge about and attitudes towards, animals changes with increasing age (Kellert 1985; Prokop, Kubiatko and Fančovičová 2008). Kellert (1985) identified three stages in the development of children's perceptions of animals. The period from six- to nine-years old is marked by emotional concern and sympathy for animals, followed by a major increase in factual knowledge and understanding of animals in ten- to thirteen-year-olds, and children thirteen- to sixteen-years old expressed their ethical concerns and ecological appreciation of animals and the natural environment.

\section{Students' ideas about birds}

Birds can be perceived in various ways: as pets (Prokop, Kubiatko and Fančovičová 2008), pests (Behrens et al. 2008), for pest control (Jones and Sieving 2006), as pollinators (Klein et al. 2007), as long-distance vectors for pathogens transmissible to humans (Tsiodras et al. 2008), for food for humans, and so on. Bird species or groups of bird species are often used as flagship organisms for biodiversity conservation campaigns because they help conservationists raise funds and change people's behavior (Verissimo et al. 2013). For example, the spotted owl (Strix occidentalis) has a symbolic position in the conservation of North American birds and their habitats, and it is at the center of a debate about the conservation of endangered species in general, and old-growth forests in particular (Gutiérrez 2008). Despite this, we found few studies that examine children's views of birds (Hummel et al. 2015; Kubiatko et al. 2011; Prokop, Kubiatko and Fančovičová, 2007, 2008; Prokop and Rodak 2009; Tunnicliffe 2011).

Prokop, Kubiatko and Fančovičová (2007) and Kubiatko et al. (2011) found that primary and lower secondary school students in Slovakia are inconsistent in their knowledge of birds and have many misconceptions. For example, in one study almost half of students did not classify the penguin as a bird (Prokop, Kubiatko and Fančovičová, 2007). Prokop et al. (2008) explored knowledge of and attitudes toward birds among students and found that students in lower grades (first, second, and fifth grade) had higher scores on a knowledge test than older students (in seventh, eighth, and ninth grades). Interest in birds decreased from first through fifth grade and gradually increased from fifth through ninth grade, but still showed rather neutral attitudes. A cross-cultural study by Hummel et al. (2015) including Colombia, Germany, Slovakia, and Turkey showed some notable differences in knowledge of, and attitudes towards, birds between students from these countries. The results also suggest that factual knowledge of birds is not a necessary prerequisite for interest in birds, but involvement in animal-related activities are strongly associated with an interest in birds. Similarly, study by Bjerke et al. (2001) including Norwegian children and adolescents found that watching natural history documentaries was associated with an interest in bird conservation.

Tunnicliffe (2011) investigated children's knowledge of pigeons (Columba palumbus) by analyzing children's drawings and interviews with them in which they were cued to talk about 
what they knew about pigeons. She found that the study of everyday animals based on interviews and drawings (on separate occasions) revealed not only biological knowledge, but also social and cultural beliefs and understandings. Germ (2006, 2008) wrote that the symbolism of birds could be recognized from a variety of art monuments, philosophical and literary writings, and descriptions of everyday life, customs, and traditions. The symbolism of birds is often derived from their appearance or behavioral characteristics.

It is known that analyzing drawings constructed by children can be used to gather information about what they know (Prokop and Fančovičová 2006; Prokop, Prokop, Tunnicliffe and Diran, 2007; Tunnicliffe and Reiss 1999b). Because there is a limit to what drawings can tell researchers, numerous studies also use interviews or written tests to investigate children's biological ideas in science (Prokop, Kubiatko and Fančovičová, 2007; Torkar and Bajd 2006). Prokop and Fančovičová (2006) suggested that using children's drawings in combination with written responses (or interviews) provides more reliable information about children's understanding of scientific phenomena. Various studies have already explored children's knowledge and conceptions about many animals and animal groups.

Owls (order Stigiformes) are birds that have been greatly neglected in educational studies. They are subdivided into two families; Tytonidae (barn owls) and Strigidae (true or typical owls) (Bruun, Delin and Svensson 2013). Owls have big heads, short necks, large, forwardfacing eyes and ear-holes, and hawk-like beak. Usually they have a facial disc around each eye. Head can be turned up to $270^{\circ}$. They are birds of prey hunting mostly by night. Usually females are larger than males. Different species of owls produce different sounds that aid owls in finding mates or announcing their presence to potential competitors. Owl species nest in hollow in trees, on top of tree stumps, in buildings, on rocks and rocky cliffs (Bruun et al. 2013). Students can potentially observe ten species of owls (Strigiformes) in Slovenia: the Eurasian eagle-owl (Bubo bubo), long-eared owl (Asio otus), Ural owl (Strix uralensis), tawny owl (Strix aluco), short-eared owl (Asio flammeus), barn owl (Tyto alba), little owl (Athene noctua), boreal owl (Aegolius funereus), Scops owl (Otus scopus), and Eurasian pygmy owl (Glaucidium passerinum). Torkar and Bajd (2006) reported that what Slovenian pre-service teachers associate the most with the word owl are large eyes and hooting. Owls were described as symbols of wisdom and death. Owls were also referred to as characters in films, fairytales, and children's songs. The owl, which takes flight at sunset and has good eyesight in the dark, is an image of the wisdom that leads people out of the darkness of a lack of knowledge (Germ 2006, 2008). Rich cultural symbolism and recognition makes owls very appropriate for conservation education (Torkar and Bajd 2006).

\section{The aim and research questions}

This study assesses what Slovenian students ten to fifteen years old (in sixth to ninth grade) know about owls by analyzing their drawings and written responses. The main aim of the research was to test if it is beneficial to obtain information about children's understanding of concepts or phenomena using their drawings in combination written responses or interviews. 
The research questions were:

1. What do Slovenian lower secondary school students know about owls?

2. What are the benefits of gathering students' knowledge concerning owls using both written responses and drawings, one after the other?

\section{Method}

\section{Respondents}

The study included 467 lower secondary school students from four schools in central Slovenia. Students attended sixth $(n=129)$, seventh $(n=132)$, eighth $(n=85)$, and ninth $(n=$ $121)$ grade. The age of students ranged between ten and fifteen years, with a mean age of 12.4 $(S D=1.18)$. In Slovenia, the educational system consists of nine years of compulsory education (from age six to fifteen). After starting school, students in first through fifth grades learn basic science concepts. In the next level of education (sixth and seventh grades), students build on their knowledge of basic science concepts, and in the last two years of compulsory education students learn more about chemistry, biology, and physics in particular.

\section{Instrument and research design}

Anonymous questionnaires were administered during regular science and biology classes. Approval from the school's head office was first acquired and written parental consent was also obtained. The work was carried out as part of a larger study focusing on student's knowledge of, and attitudes toward, owls. The questionnaire consisted of three parts. The first part gathered data about demographic variables and reported experiences with owls. In the second part, students had to report their attitudes toward owls. The third part of the questionnaire measured knowledge of owls. Children were asked to draw and to describe an owl.

\section{Data analysis}

The drawings were analyzed by the authors using a "look re-look" process to identify and consequently analyze the features of the birds that were portrayed (as in Tunnicliffe 1996, 2011). The answers to the open question were sorted out into categories. The answers with the same meaning were coded under the most frequent answer. In order to show what additional information is shown in written responses which was not provided in the drawings and vice versa we used unified categories for classifying students' ideas. Details of particular criteria used are given in the findings below (Tables 1 and 2). The chi-square test was used to test differences between the grades regarding students' drawings and written responses. An alpha level of .05 for statistical significance was used for all analyses.

\section{Results}

The analysis of students' drawings can indicate a lot about their view of reality. Drawings can reflect students' perception of the real world, but drawings could also reflect student's drawing skills rather than their knowledge of owls. Consequently, validity of claims made 
only on student's drawings could be compromised. Black-and-white drawings were more common among students. Only five percent of students used colors to draw an owl. Nine percent of students created an outline of a bird that did not particularly resemble an owl. Drawings included basic features of birds such as legs, a body, wing(s), a head, and a beak. Most students (90.5\% of answers in category physical characteristics of owls) drew an owl with some distinctive features for this group of birds. Remaining 5\% created detailed drawings of a typical (generic, recognisable) owl. Their artistic images show very good drawing skills. On this drawings are very specific features and accurate shapes and body proportions (Figure 1).

Figure 1. Students' drawings of owls in three categories: 1) outline of a bird, 2) outline of an owl and its basic features, 3) realistic depiction of an owl.

Table 1 presents the characteristics of students' drawings of owls that were analyzed. Most frequently they drew owl's body (100.0\%), large eyes (99.1\%), wings (98.1\%), a beak (97.9\%), legs $(95.3 \%)$, a rounded head $(93.8 \%)$, ear tufts $(79.0 \%)$, and feathers $(65.3 \%)$. These drawings show some features (physical characteristics) that students associate with owls (i.e., rounded head, ear tufts).

In their drawings, two thirds of students depicted owls with no relation to other species. Only a few students (20 out of 467 students) drew more than one owl. They drew more adult specimens, or an adult and juveniles, or an adult with eggs in the nest. 35.5\% of students depicted them in their habitat. The birds were drawn in forests and trees, including other organisms such as prey animals. The differences between students in different grades regarding the depiction of habitat proved to be significant $\left(\chi^{2}(3)=12.85, p<0.05\right)$. The percentage of students drawing owls in their habitats was higher among students in seventh (44\%) and eighth grade (42\%), than among students in ninth grade (26\%). The prey animals drawn by students were mice, insects, worms, and other birds. Two students drew an owl in a nighttime context, showing stars, the Moon, and the owl wide awake, depicting it as a night bird (Figure 2).

Figure 2. A student's drawing of an owl in a night scene.

Table 1. Analysis of students' drawings of owls by grade.

Almost half of the students depicted owls exhibiting behavior such as flying, walking, or sitting in a tree. Most of the depictions showed them sitting on a tree branch or in a hole in a tree $(35.5 \%)$, which is also typically seen in the wild. Although flying is typical for birds, only $3.5 \%$ of the students presented this behavior in their drawings. A walking owl was an even less frequent depiction (1.9\%). There were no significant differences between the grades regarding drawing owls' behavior.

In the same way as the analysis of students' drawings, analyzing students' written responses reveals their perception of owls and information they know about their biology (Table 2). Most of the students written descriptions of owls were classified into category physical characteristics (39.0\% of answers). They most frequently mentioned owl's large eyes (38.7\%) 
and rounded head (26.4\%). Students regularly confused the long ear-tufts of the long-eared owl (Asio otus) and the Eurasian eagle owl (Bubo bubo), both native in Slovenia, with external parts of the ears. A few of them mistakenly thought that the Slovenian word sova 'owl' referred to a female little owl (Athene noctua; Slovenian čuk).

Second most commonly mentioned category in written responses was behavior of owls (34.8\% of answers). Altogether, $68.0 \%$ of the students pointed out that the owl is a nocturnal bird and therefore has good night vision (13.2\%) and hearing (13.0\%). Sixteen percent of students mentioned hooting as a typical characteristic of owls and $26.2 \%$ of them emphasized that owls twist their heads, but a few of them mistakenly think that owls can turn their heads 360 degrees.

Owls' diet (mice, insects and worms) (9.4\% of answers) and habitat (8.8\% of answers) seemed to be important information for describing them. Students were mentioning forests and tree holes (80.9\%) and rocks (16.7\%), In the category "other answers," answers like birds of prey, juveniles, eggs, species diversity, wisdom, death, and other associations were classified. Last but not least, a few students (3.5\% of answers or $7.9 \%$ of students) mentioned owls' conservation status. They wrote that owls are endangered and protected bird species.

The differences between students in different grades regarding the categories describing owls in their written responses proved to be not statistically significant, except in the case of "good hearing" $\left(\chi^{2}(3)=8.30, p<0.05\right)$. The share of students mentioning the feature "good hearing" was significantly higher among students in eighth grade $(22.4 \%)$ than students in seventh grade $(3.9 \%)$.

Table 2. Analysis of students' written descriptions of owls.

A comparison of students' drawings and written responses was made to answer the second research question. From the analysis of drawings, good information can be gathered about students' depictions of owls' physical characteristics such as the shape and proportion of the body, wings, eyes, legs, etc. Ninety percent of all features on drawings were categorized into this category. In comparison to their written responses, where $39.0 \%$ of the answers were categorized into the same category; the students named owl's eyes, head and other features and often described the purpose of specific features for owls. They pointed out good eyesight, good hearing, the ability to turn their heads etc. which was not possible to determine from the drawings. Two thirds drew an isolated specimen or specimens with no relation to their habitat, but in their written responses $80.9 \%$ pointed out that owls live in forests and trees and $16.7 \%$ in rocks. Very few drawings depicted owl's diet but 39.2\% of students wrote about diet, most commonly mentioning mice. Students' drawings depicted the behavior of an owl in its natural habitat, such as flying, sitting in a tree, or walking on the ground. In their written responses, students rarely mentioned behaviors general for birds (i.e., flying), however, many students talked about hooting (16.0\%) and turning the head (26.2\%), which was not depicted in the drawings. They also wrote that owls are nocturnal birds (68.0\%), but only 2 drawings showed owls in a nighttime scene. The written responses also mentioned some other information about owls, such as the diversity of owl species and their conservation status, which was not depicted in the drawings. 


\section{Discussion}

Students' drawn and verbal representations show that majority of students know what an owl looks like. Drawings and written descriptions of owls are external representations of mental models that children have acquired over time (Tunnicliffe 2011). From assessing students' drawings and written responses, it can be concluded that the respondents had some knowledge of owls' appearance, their behaviors, diet and habitats. Tunnicliffe (2011) wrote that primary school students expressed their mental models about pigeons extrapolated from their knowledge of themselves or the behavior of birds they knew. She stated that some students' ideas may be reinforced by cartoons and popular stories, such as the concept that all birds eat worms. This study cannot confirm that students mainly expressed their ideas about owls by extrapolating from their general knowledge of birds. It may be that owls, due to their rich symbolism and appearance in children's literature, stand out as a more recognized and attractive group of birds. Consequently, students were familiar with some of the specific features of owls that differentiate them from other birds (e.g. large head and eyes, hooting).

Many drawings and written responses included descriptions of owls' habitat (i.e., in trees and forests), which makes owls good candidates for promoting forest conservation, such as in the case of the spotted owl (Strix occidentalis; Gutiérrez 2008). Students mentioned only trees and forests or rocks as owls' habitats. Habitats of owls living in anthropogenic environments, like of barn owls, were not described or depicted by students.

Some misconceptions were found in students' written responses and drawings. Some mistakenly thought that the word "owl" is female specimen of the species little owl (Athene noctua). This misconception may be connected with a popular children's song in which a little owl is married to an owl. Similarly, Prokop et al. (2008) found that many Slovakian primary school students have misconceptions about owls; for example, they believed that an owl's eyes light up at night or that owls see only at night. Future research should address the source of these student misconceptions in greater detail.

According to Kellert (1985), students ten to thirteen years old rapidly progress in factual knowledge and understanding of animals, and from age thirteen to sixteen they express their ethical concerns and ecological appreciation of animals and the natural environment. In this study, the respondents, age ten to fifteen, had some factual knowledge and understanding of owls, and some students reported the conservation status of these bird species. However, significant differences in students' written responses by grades were detected only when mentioning owls' good hearing and the depiction of habitat.

Any mode of external representation of biological ideas, concepts, or phenomena uses a special way of representing real-life objects. Visualization is especially important in biology education because the objects studied are usually very complex biological systems. Tsui and Treagust (2013) presented modes of representations as a continuum of increasing abstraction, on which human language is the most abstract mode. As proposed by Prokop and Fančovičová (2006), a combination of children's drawings and written responses could provide more reliable information about children's ideas. This study assessed ten- to fifteen- 
year-old students' knowledge of owls by analyzing two modes of external representations: drawings of owls (a very realistic mode) and written descriptions of owls (the most abstract mode). The results show that students' written responses provided more information on their ideas about owls; particularly about owls' specific behaviors, diet, and conservational status. However, some information, such as depicting owls' body parts and body proportions or their habitats, could be more clearly depicted with drawings. In our future research, we plan to repeat the study with Slovenian students in third and fifth grade (eight to ten years old). The main research goal will be to investigate the benefits of gathering students' knowledge from written responses and drawings and to compare the results with this study. Our assumption is that children's drawings will complement the written responses better than in this study because younger children are less literate and consequently more limited in their verbal expression.

\section{References}

Behrens, V., F. Rauschmayer, and H. Wittmer. 2008. "Managing International "Problem" Species: Why Pan-European Cormorant Management Is So Difficult.” Environmental Conservation 35 (1), 55-63.

Bjerke, T., B. Kaltenborn, and T. Ødegårdstuen. 2001. "Animal-Related Activities and Appreciation of Animals among Children and Adolescents." Anthrozoos 14 (2), 86-94.

Bruun, B., Delin, H, and Svensson, L. 2013. Hamlyn Guide Birds of Britain and Europe. London: Bounty Books.

Germ, T. 2006. Simbolika živali [Symbolism of animals]. Ljubljana: Modrijan.

Germ, T. 2008. "Simbolika ptic [Symbolism of birds]." Svet ptic 14 (2), 6-9.

Gutiérrez, R. J. 2008. "Spotted Owl Research: A Quarter Century of Contributions to Education, Ornithology, Ecology, and Wildlife Management.” The Condor, 110 (4), 792-798.

Hatano, G., and K. Inagaki. 1997. "Qualitative Changes in Intuitive Biology." European Journal of Psychology of Education 21 (2), 11-130.

Hummel, E., J. Fančovičová, C. Randler, M. Ozel, M. Usak, W. Medina-Jerez, and P. Prokop. 2015. "Interest in Birds and Its Relationship with Attitudes and Myths: A CrossCultural Study in Countries with Different Levels of Economic Development." Educational Sciences: Theory and Practice 15 (1), 285-296.

Inagaki, K. 1990. "The Effects of Raising Animals on Children's Biological Knowledge." British Journal of Developmental Psychology 8 (1), 119-129.

Jones, G. A., and K. E. Sieving. 2006. Intercropping Sunflower in Organic Vegetables to Augment Bird Predators of Arthropods." Agriculture, Ecosystems \& Environment 117 (2-3), 171-177. 
Kellert, S. R. 1985. “Attitudes toward Animals: Age-Related Development among Children” Journal for Environmental Education 16, 29-39.

Klein, A.-M., B. Vaissiere, J. Cane, I. Steffan-Dewenter, S. K Cunningham, and T. Tscharntke. 2007. "Importance of Pollinators in Changing Landscapes for World Crops." Proceedings of the Royal Society B 274 (1608), 303-313.

Kubiatko, M., M. Usak, and E. Pecušová. 2011. “Elementary School Pupils’ Knowledge and Misconceptions about Birds.” Eurasian Journal of Educational Research 11 (43), $136-181$.

Prokop, P., and J. Fančovičová. 2006. “Students’ Ideas about the Human Body: Do They Really Draw What They Know?.” Journal of Baltic Science Education 2 (10), 86-95.

Prokop, P., M. Kubiatko, and J. Fančovičová. 2007. "Why Do Cocks Crow? Children's Concepts about Birds." Research in Science Education 37 (4), 393-405.

Prokop, P., M. Kubiatko, and J. Fančovičová. 2008. "Slovakian Pupils’ Knowledge of and Attitudes toward Birds.” Anthrozoös 21 (3), 221-235.

Prokop, P., M. Prokop, S. D. Tunnicliffe, and Diran, C. 2007. "Ideas of Animals' Internal Structures.” Journal of Biological Education 41 (2), 142-148.

Prokop, P., and R. Rodak. 2009. “Ability of Slovakian Pupils to Identify Birds.” Eurasia Journal of Mathematics, Science and Technology Education 5 (2), 127-133.

Prokop, P., and S. Tunnicliffe. 2010. "Effects of Having Pets at Home on Children's Attitudes toward Popular and Unpopular Animals.” Anthrozoös 23 (1), 21-35.

Torkar, G., and B. Bajd. 2006. “Trainee Teachers' Ideas about Endangered Birds.” Journal of Biological Education 41 (1), 5-8.

Tsiodras, S., T. Kelesidis, I. B. Kelesidis, and M. E. Falagas. 2008. "Human Infections Associated with Wild Birds.” Journal of Infection 56 (2), 83-98.

Tsui, C. Y., and D. F. Treagust. 2013. Introduction to Multiple Representations: Their Importance in Biology and Biological Education. In Multiple Representations in Biological Education, edited by Treagust, D. F., and C. Y. Tsui, 3-18. Dordrecht: Springer.

Tunnicliffe, S. D. 1996. Conversations within Primary School Parties Visiting Animal Specimens in a Museum and Zoo.” Journal of Biological Education 30 (2), 130-141.

Tunnicliffe, S. D. 2011. "Visualisation of Animals by Children: How Do They See Birds? CEPS Journal 1 (4), 63-80.

Tunnicliffe, S. D., S. Gatt, C. Agius, and S. A. Pizzuto. 2008. "Animals in the Lives of Young Maltese Children." Eurasia Journal of Mathematics, Science \& Technology 4 (3), 215-221. 
Tunnicliffe, S. D., and M. J. Reiss. 1999. "Building a Model of the New Environment: How Do Children See Animals?.” Journal of Biological Education 33 (3), 142-148.

Tunnicliffe, S. D., and M. J. Reiss. 1999. "Students' Understanding about Animal Skeletons." International Journal of Science Education 21 (11), 1187-1200.

Veríssimo, D., T. Pongiluppi, M. C. Santos, O. F. Develey, I. Fraser, R. J. Smith, and D.C. MacMillan. 2013. "Using a Systematic Approach to Select Flagship Species for Bird Conservation." Conservation Biology 28 (1), 269-277. 
Table 1. Analysis of students' drawings of owls by grade

\begin{tabular}{|c|c|c|c|c|c|c|c|c|c|c|}
\hline \multirow{2}{*}{$\begin{array}{l}\text { Categories* } \\
\qquad \text { Subcategories** }\end{array}$} & \multicolumn{2}{|c|}{$\begin{array}{l}\text { Sixth } \\
\text { grade }\end{array}$} & \multicolumn{2}{|c|}{$\begin{array}{l}\text { Seventh } \\
\text { grade }\end{array}$} & \multicolumn{2}{|c|}{$\begin{array}{l}\text { Eighth } \\
\text { grade }\end{array}$} & \multicolumn{2}{|c|}{$\begin{array}{l}\text { Ninth } \\
\text { grade }\end{array}$} & \multicolumn{2}{|c|}{ Total } \\
\hline & $f$ & $f \%$ & $f$ & $f \%$ & $f$ & $f \%$ & $f$ & $f \%$ & $f$ & $f \%$ \\
\hline Physical characteristics & 1020 & 90.7 & 1054 & 88.5 & 695 & 90.4 & 945 & 92.7 & 3714 & 90.5 \\
\hline Body & 129 & 100.0 & 132 & 100.0 & 85 & 100.0 & 119 & 98.3 & 467 & 100.0 \\
\hline Eyes & 127 & 98.4 & 131 & 99.2 & 84 & 98.8 & 121 & 100.0 & 463 & 99.1 \\
\hline Wings & 126 & 97.7 & 129 & 97.7 & 85 & 100.0 & 117 & 96.7 & 458 & 98.1 \\
\hline Beak & 126 & 97.7 & 128 & 97.0 & 85 & 100.0 & 118 & 97.5 & 457 & 97.9 \\
\hline Legs & 126 & 97.7 & 123 & 93.2 & 85 & 100.0 & 111 & 91.7 & 445 & 95.3 \\
\hline Head & 117 & 90.7 & 124 & 93.9 & 82 & 96.5 & 115 & 95.0 & 438 & 93.8 \\
\hline Ears & 99 & 76.7 & 105 & 79.5 & 68 & 80.0 & 97 & 80.2 & 369 & 79.0 \\
\hline Feather & 74 & 57.4 & 91 & 68.9 & 56 & 65.9 & 84 & 69.4 & 305 & 65.3 \\
\hline Claws & 64 & 49.6 & 68 & 51.5 & 38 & 44.7 & 44 & 36.4 & 214 & 45.8 \\
\hline Tail & 24 & 18.6 & 15 & 11.4 & 25 & 29.4 & 17 & 14.0 & 81 & 17.3 \\
\hline Colour & 8 & 6.2 & 8 & 6.1 & 0 & 0.0 & 1 & 0.8 & 17 & 3.6 \\
\hline Size & 0 & 0.0 & 0 & 0.0 & 0 & 0.0 & 1 & 0.8 & 1 & 0.2 \\
\hline Behaviours of owls & 49 & 4.4 & 70 & 5.9 & 34 & 4.4 & 40 & 3.9 & 193 & 4.7 \\
\hline Sitting in a tree & 39 & 30.2 & 62 & 47.0 & 31 & 36.5 & 35 & 28.9 & 167 & 35.8 \\
\hline Flying & 7 & 5.4 & 6 & 4.5 & 1 & 1.2 & 3 & 2.5 & 17 & 3.6 \\
\hline Walking & 3 & 2.3 & 2 & 1.5 & 2 & 2.4 & 2 & 1.7 & 9 & 1.9 \\
\hline Habitats of owls & 42 & 3.7 & 58 & 4.9 & 35 & 4.6 & 31 & 3.0 & 166 & 4.0 \\
\hline Forest and trees & 42 & 32.6 & 58 & 43.9 & 35 & 41.2 & 31 & 25.6 & 166 & 35.5 \\
\hline $\begin{array}{l}\text { Depiction of more than } \\
\text { one owl }\end{array}$ & 8 & 0.7 & 7 & 0.6 & 4 & 0.5 & 1 & 0.1 & 20 & 0.5 \\
\hline Other species & 3 & 0.3 & 1 & 0.1 & 1 & 0.1 & 1 & 0.1 & 6 & 0.1 \\
\hline Diet of owls & 3 & 0.3 & 1 & 0.1 & 0 & 0.0 & 1 & 0.1 & 5 & 0.1 \\
\hline
\end{tabular}

* Proportion of answers (f \%)

**Proportion of students ( $f \%$ ) 
Table 2. Analysis of students' written descriptions of owls.

\begin{tabular}{|c|c|c|c|c|c|c|c|c|c|c|}
\hline \multirow{2}{*}{$\begin{array}{l}\text { Categories* } \\
\text { Subcategories** }\end{array}$} & \multicolumn{2}{|c|}{$\begin{array}{l}\text { Sixth } \\
\text { grade }\end{array}$} & \multicolumn{2}{|c|}{$\begin{array}{l}\text { Seventh } \\
\text { grade }\end{array}$} & \multicolumn{2}{|c|}{$\begin{array}{l}\text { Eighth } \\
\text { grade }\end{array}$} & \multicolumn{2}{|c|}{$\begin{array}{l}\text { Ninth } \\
\text { grade }\end{array}$} & \multicolumn{2}{|c|}{ Total } \\
\hline & $f$ & $f \%$ & $f$ & $f \%$ & $f$ & $f \%$ & $f$ & $f \%$ & $f$ & $f \%$ \\
\hline Physical characteristics & 215 & 39.5 & 215 & 39.4 & 120 & 34.9 & 212 & 40.9 & 762 & 39.0 \\
\hline Eyes & 41 & 32.3 & 52 & 40.3 & 38 & 44.7 & 48 & 39.7 & 179 & 38.7 \\
\hline Head & 38 & 29.9 & 30 & 23.3 & 23 & 27.1 & 31 & 25.6 & 122 & 26.4 \\
\hline Size & 28 & 22.0 & 28 & 21.7 & 10 & 11.8 & 26 & 21.5 & 92 & 19.9 \\
\hline Beak & 20 & 15.7 & 20 & 15.5 & 9 & 10.6 & 25 & 20.7 & 74 & 16.0 \\
\hline Colour & 23 & 18.1 & 21 & 16.3 & 5 & 5.9 & 22 & 18.2 & 71 & 15.4 \\
\hline Feather & 15 & 11.8 & 16 & 12.4 & 9 & 10.6 & 22 & 18.2 & 62 & 13.4 \\
\hline Claws & 21 & 16.5 & 17 & 13.2 & 7 & 8.2 & 12 & 9.9 & 57 & 12.3 \\
\hline Wings & 12 & 9.4 & 16 & 12.4 & 9 & 10.6 & 14 & 11.6 & 51 & 11.0 \\
\hline Ears & 12 & 9.4 & 8 & 6.2 & 6 & 7.1 & 4 & 3.3 & 30 & 6.5 \\
\hline Legs & 5 & 3.9 & 5 & 3.9 & 4 & 4.7 & 5 & 4.1 & 19 & 4.1 \\
\hline Body & 0 & 0.0 & 1 & 0.8 & 0 & 0.0 & 2 & 1.7 & 3 & 0.6 \\
\hline Tail & 0 & 0.0 & 1 & 0.8 & 0 & 0.0 & 1 & 0.8 & 2 & 0.4 \\
\hline Behaviour of owls & 195 & 35.8 & 183 & 33.5 & 131 & 38.1 & 170 & 32.8 & 679 & 34.8 \\
\hline Active at night & 81 & 63.8 & 93 & 72.1 & 60 & 70.6 & 80 & 66.1 & 314 & 68.0 \\
\hline Turning the head & 38 & 29.9 & 29 & 22.5 & 23 & 27.1 & 31 & 25.6 & 121 & 26.2 \\
\hline Hooting & 20 & 15.7 & 18 & 14.0 & 12 & 14.1 & 24 & 19.8 & 74 & 16.0 \\
\hline Flying & 17 & 13.4 & 19 & 14.7 & 12 & 14.1 & 13 & 10.7 & 61 & 13.2 \\
\hline Good eyesight & 23 & 18.1 & 19 & 14.7 & 5 & 5.9 & 13 & 10.7 & 60 & 13.0 \\
\hline Good hearing & 16 & 12.6 & 5 & 3.9 & 19 & 22.4 & 9 & 7.4 & 49 & 10.6 \\
\hline Diet of owls & 49 & 9.0 & 50 & 9.2 & 39 & 11.3 & 45 & 8.7 & 183 & 9.4 \\
\hline Habitats of owls & 44 & 8.1 & 57 & 10.4 & 27 & 7.8 & 43 & 8.3 & 171 & 8.8 \\
\hline Forest and trees & 32 & 25.2 & 42 & 32.6 & 22 & 25.9 & 35 & 28.9 & 131 & 28.4 \\
\hline Rocks & 9 & 7.1 & 10 & 7.8 & 3 & 3.5 & 5 & 4.1 & 27 & 5.8 \\
\hline Other & 3 & 2.4 & 5 & 3,9 & 2 & 2,4 & 3 & 2.5 & 13 & 2.8 \\
\hline Other species & 30 & 5.5 & 32 & 5.9 & 21 & 6.1 & 37 & 7.1 & 120 & 6.1 \\
\hline $\begin{array}{l}\text { Conservation and } \\
\text { protection }\end{array}$ & 11 & 2.0 & 9 & 1.6 & 6 & 1.7 & 11 & 2.1 & 37 & 1.9 \\
\hline No answer & 2 & & 3 & & 0 & & 0 & & 5 & \\
\hline
\end{tabular}

* Proportion of answers ( $f \%)$

**Proportion of students ( $f \%$ ) 